\title{
Edta, Water-Extractable Arsenic and Bioavailability of Arsenic in Soil/Tailings: the Effects of Zeolite and Beringite Amendments
}

\author{
Benjamin Appiah Osei (Corresponding author)
}

Department of Soil Science, University of Cape Coast, GHANA. E-mail:bosei@ucc.edu.gh

Mohammed Rufai Ahmed

Department of Agronomy, University for Development Studies, Tamale, GHANA.

Received: November 17, 2017

doi:10.5296/jas.v6i1.12699
Accepted: December 1, 2017

URL: https://doi.org/10.5296/jas.v6i1.12699

\begin{abstract}
The effects of zeolite and beringite ( 0,30 and $\left.60 \mathrm{~kg} \mathrm{ha}^{-1} \mathrm{w} / \mathrm{w}\right)$ on EDTA-extractable Arsenic (As), water soluble As, and bioavailability of arsenic (As) in non-mined agricultural soil and tailings of a mined site(capped and uncapped) were studied in a pot experiment. Un-amended non-mined agricultural soil was included as a control. EDTA-extractable and water extractable forms of As were monitored for 0-12-weeks after amendments and bioavailability of As was evaluated by growing lettuce (Lactuca sativa) on amended tailings/soil for 4-12 weeks after incubation. For EDTA-extractable As at week 12, beringite amendment (60 kg $\mathrm{ha}^{-1}(\mathrm{w} / \mathrm{w})$ was $29 \%, 8.6 \%$ and $26 \%$ more efficient over zeolite for soil/capped and uncapped tailings respectively. For water-extractable As at week 12, beringite amendment 60 $\mathrm{kg} \mathrm{ha}^{-1}(\mathrm{w} / \mathrm{w})$ again recorded $84 \%, 54.5 \%$ and $72 \%$ less extractable As over zeolite in soil/capped and uncapped tailings respectively. Analysis for bioavailable-As in edible leafy aerial parts of lettuce, indicated $52.5 \%, 82.0 \%$ and $39.0 \%$ less extractable As for beringte over zeolite in capped and uncapped tailings (week 12, $60 \mathrm{~kg} \mathrm{ha}^{-1}(\mathrm{w} / \mathrm{w}) \ldots$ Beringite (week 12, $\left.60 \mathrm{~kg} \mathrm{ha}^{-1} \mathrm{w} / \mathrm{w}\right)$ reduced As of capped tailing $\left(0.3 \mathrm{mg} \mathrm{kg}^{-1}\right)$ below the FAO \& WHO recommended maximum limit of $1.0 \mathrm{mg} \mathrm{kg}^{-1}$ for human consumption.
\end{abstract}

Keywords: Immobilization, solubility, mobility, remediated soil, Lactuca sativa 


\section{MIN Macrothink}

\section{Introduction}

Arsenic (As) is a frequently found contaminant in contaminated sites. This is due to its many industrial applications. Owing to its toxic nature, soil contamination by arsenic has always been a major environmental concern. Apart from its ability to bio-accumulate in edible plant parts and enter the food chain, arsenic contaminated soils could be transported by wind and run-off into community water sources. Exposure to arsenic has been linked to a variety of cancers, cardiovascular disease, diabetes, and anemia, as well as having reproductive, developmental, immunological, and neurological effects (US EPA, 2003). Methods used to remediate arsenic contaminated soils include phytoremediation, solidification/stabilization, fixation, vitrification, soil flushing, and electro kinetic remediation ( Date, Terakado, Sasaki, Aota, Matsumoto, Shiku, Inoa, Watanabe, Matsue \& Ohmura, 2012; Jiang, Tao \& Liao, 2011). A common objective of these methods is to reduce the hazard potential of the waste by limiting its solubility and mobility. Chemical stabilization has received wide patronage for arsenic-contaminated soil in recent years, probably because of its cost effectiveness. The conventional soil remediation technologies, although suitable for relatively small and heavily contaminated areas, are financially and physically inefficient in extensive and moderately contaminated soils. The capping of contaminated tailings with lateritic soil as practiced by some mining companies in Ghana does not remove arsenic from the soil/tailings. Amendments that have been screened for their potential to immobilize heavy metals in soils are alkaline materials such as beringite and zeolite (Edwards, Rebedea, Lepp, \& Lovell, 1999.; Oste, Lexmond, \& Van Riemsdijk, 2002; Mench, Vansgronsveld, Beckx, \& Ruttens, 2006).

The bioavailability of heavy metals in mediated soils can be assessed by growing plants such as lettuce that bio-accumulate substantial amounts of these metals in their edible aerial parts (Nadia \& Zaghlou, 2007). The objective of this study therefore was to assess the effectiveness of zeolite and beringite on the forms and bioavailability of arsenic (As) in non-mined agricultural soil, capped and uncapped tailings of a mined site.

\section{Materials and Methods}

Soil and tailings used in this study were sampled from a mining site in Ghana. These were reclaimed tailings (capped and uncapped), and a non-mined agricultural soil (control). Top soils/tailing samples $(0-15 \mathrm{~cm}$ depth) were collected. Forty soil cores each were taken for non-mined, capped tailings and uncapped tailings, bulked into three composite samples and transported to the laboratory. The samples were prepared by air drying, crushing, discarding of foreign material and sieving through a 2-mm nylon mesh. The properties of soil/tailings are presented in Table 1. 
Table 1. Properties of soil/tailings at $0-15 \mathrm{~cm}$ depth

Site

Properties

$\begin{array}{lll}\text { None Mined } & \text { Capped } & \text { Uncapped } \\ & \text { Tailings } & \text { Tailings }\end{array}$

\begin{tabular}{|c|c|c|c|}
\hline Organic carbon $(\%)$ & 2.13 & 0.63 & 1.02 \\
\hline Total N (\%) & 0.19 & 0.06 & 0.10 \\
\hline $\mathrm{C}: \mathrm{N}$ ratio & 11.21 & 10.50 & 10.20 \\
\hline $\mathrm{pH}$ (1:2.5 soil:water) & 5.10 & 6.79 & 7.22 \\
\hline P - Bray I (mg kg $\left.{ }^{-1}\right)$ & 6.58 & 16.57 & 1.53 \\
\hline $\mathrm{Ca}^{+2}\left(\mathrm{cmol}_{\mathrm{c}} \mathrm{kg}^{-1}\right)$ & 3.47 & 11.75 & 15.39 \\
\hline $\mathrm{Mg}^{+2}\left(\mathrm{cmol}_{\mathrm{c}} \mathrm{kg}^{-1}\right)$ & 1.60 & 8.54 & 9.61 \\
\hline $\mathrm{K}^{+}\left(\mathrm{cmol}_{\mathrm{c}} \mathrm{kg}^{-1}\right)$ & 0.21 & 0.42 & 1.40 \\
\hline $\mathrm{Na}^{+}\left(\mathrm{cmol}_{\mathrm{c}} \mathrm{kg}^{-1}\right)$ & 0.13 & 0.42 & 1.67 \\
\hline $\operatorname{CEC}\left(\mathrm{cmol}_{\mathrm{c}} \mathrm{kg}^{-1}\right)$ & 5.41 & 21.13 & 28.07 \\
\hline $\begin{array}{l}\text { Exhange Acidity } \\
\left(\mathrm{cmol}_{\mathrm{c}} \mathrm{kg}^{-1}\right)\end{array}$ & 0.35 & 0.10 & 0.05 \\
\hline $\begin{array}{r}\text { Effective CEC } \\
\left(\text { cmocl }_{\mathrm{c}} \mathrm{kg}^{-1}\right)\end{array}$ & 5.76 & 21.23 & 28.12 \\
\hline Bulk density $\left(\mathrm{g} \mathrm{cm}^{-3}\right)$ & 1.26 & 1.33 & 1.39 \\
\hline Total Porosity (\%) & 52.5 & 49.8 & 47.5 \\
\hline Sand $(\%)$ & 44 & 49 & 35 \\
\hline Silt $(\%)$ & 46 & 41 & 61 \\
\hline Clay (\%) & 10 & 10 & 4 \\
\hline
\end{tabular}

\subsection{Soil Amendment and Incubation Experiment}

Five hundred grams (500 g) air dry soil/tailings from each of the three sites were placed in $0.5 \mathrm{~L}$ plastic containers. The soil/tailings were amended with zeolite and beringite at the rates of 0,30 and $60 \mathrm{~kg} \mathrm{ha}^{-1}(\mathrm{w} / \mathrm{w})$. The amendments were thoroughly incorporated into soil/tailings and moistened to field capacity. Each amendment was replicated there times. The completely randomized design was used. The samples were incubated at room temperature of $25{ }^{\circ} \mathrm{C}$ in the laboratory and moistened weekly to maintain soil moisture at $60 \%$ field capacity. The soil/tailings were sampled at $0,4,8$ and 12 weekly intervals, mixing thoroughly before sampling. Five random sub-samples were taken with a spatula from each container and bulked for analysis. 


\subsection{Extraction of (EDTA) - As}

Ten (10) grams of air-dried soil/tailings were weighed and pulverized in a clean, nitric acid washed mortar and pestle, for the Ammonium tetra sodium-ethylene-diamine-tetraacetic acid ( $\mathrm{Na}_{4}-\mathrm{NH}_{4}$-EDTA) extraction (ADAS, 1986; Sabiene, Brazuaskiene \& Rimmer, 2004). The soil was wrapped in a paper towel before being pulverized with the mortar and pestle to minimize the nitric acid washing necessary for the mortar and pestle. The soil was placed into a $100 \mathrm{ml}$ conical flask and $50 \mathrm{ml}$ of $0.05 \mathrm{M}\left(\mathrm{Na}_{4}-\mathrm{NH}_{4}\right.$-EDTA) ( $\left.\mathrm{pH} 7\right)$ was added. The flask with the soil: $\mathrm{Na}_{4}-\mathrm{NH}_{4}$-EDTA mixture was shaken at room temperature on a mechanical shaker at $125 \mathrm{rpm}$ for $1 \mathrm{hr}$. (ADAS, 1986; Sabiene, Brazuaskiene \& Rimmer, 2004). The slurry was then passed through a Whatman's no. 42 filter paper into a sterile $100 \mathrm{ml}$ conical flask. The filtrate was brought to exactly $100 \mathrm{ml}$ with the extraction solution. The filtrate was analyzed using the Atomic Absorption Spectrophotometer (AAS). The concentrations of As was measured at wavelengths of $193.7 \mathrm{~nm}$.

\subsection{Extraction of Water Soluble As}

Water soluble As was determined by weighing $5.0 \mathrm{~g}$ of soil/tailings samples into centrifuge tubes and $50 \mathrm{ml}$ of distilled water added. The tubes were capped and shaken for $30 \mathrm{~min}$. After shaking, the content of the tube was filtered with Whatman no.42 filter paper. Arsenic levels in the extracts were determined by AAS at a wavelength of $193.7 \mathrm{~nm}$.

\subsection{Bioavailability Experiment and Plant Analysis}

Lettuce (Lactuca sativa) was chosen as the plant indicator of the bioavailability of As for its ability to accumulate heavy metals in the edible leafy aerial parts (Nadia \& Zaghloul, 2007). The field practices for the cultivation of lettuce as described by (Grubben, 2004) were followed. The lettuce seeds were planted in a seedbed that was shaded with oil palm fronds. The seedlings were pricked out three weeks after germination and planted at a spacing of 4 $\mathrm{cm} \times 4 \mathrm{~cm}$. The seedlings were natured for another three weeks and subsequently transplanted into the containers/pots containing the mediated non-mined soil/tailings which were incubated for 3 weeks. The soil/tailings samples were then moistened to $60 \%$ of field capacity and then moistened weekly to maintain moisture at $60 \%$ field capacity. Fertilizer was incorporated into the soil/tailings samples at the rates of $50 \mathrm{~kg} \mathrm{~N} \mathrm{ha}^{-1}, 45 \mathrm{~kg} \mathrm{P}^{-1}$ and 65 $\mathrm{kg} \mathrm{K} \mathrm{ha}{ }^{-1}$ at the time of transplanting. Three-weeks after transplanting, $50 \mathrm{~kg} \mathrm{~N} \mathrm{ha}{ }^{-1}$ was applied as recommended by (Grubben, 2004). The aerial parts of the lettuce plants were harvested and prepared for the analysis for Arsenic. One (1.0) g of prepared plant material was digested in freshly prepared mixture of $\mathrm{HNO}_{3}-\mathrm{HCl}(1: 3 \mathrm{v} / \mathrm{v})$ on a digester at $110{ }^{\circ} \mathrm{C}$ for three hours to determine the concentration of As.

\subsection{Data Analysis}

The GenStat statistical package (GenStat, 2016) was used for the analysis of data. The analysis of variance (ANOVA) was used to determine the effects of the amendments on water-soluble and EDTA-extractable As in the non-mined soil, capped and uncapped tailings. The least significant difference (LSD) was used for the separation of means (95\% confidence level). The percentage change was used to explain the differences in the effects of the 
amendments. The percentage change in treatment effect on the value of the variable (arsenic) was estimated from the relationship:

$$
\% \Delta \text { Varible }=100\left(\frac{V_{\mathrm{X} \text { Rate }}-V_{0}}{V_{0}}\right)
$$

The percentage change in value of variable at given rate of application of amendment is represented by $\% \Delta$ Variable, the value of the variable at a specific rate of application is given by $\mathrm{V}_{\mathrm{X}}$ Rate and the value of the variable at $0 \mathrm{~kg}$ ha- 1 rate of application is represented by $\mathrm{V}_{0}$.

\section{Results and Discussion}

\subsection{Effects of Amendments on EDTA-extractable Arsenic in Non-Mined Soil, Capped and}

\section{Uncapped Tailings}

The results of EDTA-extractable arsenic (As), in non-mined soil, capped and uncapped tailings following beringite and zeolite amendment are presented in tables 2, 3 and 4 . At 4 weeks after incubation (WAI), there were significant $(\mathrm{P}=0.05)$ differences in EDTA-As between beringite amendments (30 and $60 \mathrm{~kg} \mathrm{ha}^{-1}$ ) and the control in non - mined, capped and uncapped tailings. The concentration of EDTA-As was significantly lower when beringite was applied at $60 \mathrm{~kg} \mathrm{ha}^{-1}\left(15.46 \mathrm{mg} \mathrm{kg}^{-1}\right)$ than at $30 \mathrm{~kg} \mathrm{ha}^{-1}\left(17.02 \mathrm{mg} \mathrm{kg}^{-1}\right)$ and decreased by $21.8 \%$ and $13.9 \%$, respectively compared to the non-amended non-mined soil at 4 WAI. The concentration of EDTA-As, when beringite was applied to capped tailings at $60 \mathrm{~kg} \mathrm{ha}^{-1}\left(135.3 \mathrm{mg} \mathrm{kg}^{-1}\right)$ and $30 \mathrm{~kg} \mathrm{ha}^{-1}\left(160.7 \mathrm{mg} \mathrm{kg}^{-1}\right)$ decreased by $24.5 \%$ and $10.3 \%$, respectively compared to the non-amended soil at 4 WAI (Table 3). A similar trend was observed for beringite-amended uncapped tailings at 4 WAI (Table 4). Generally, the concentrations of EDTA-As beringite applied at the rates of 30 and $60 \mathrm{~kg} \mathrm{ha}^{-1}$ were significantly lower than $(\mathrm{P}=0.05)$ that of non-amended non-mined soil, capped and uncapped tailings from 8 WAI to 12 WAI (Tables 2, 3 and 4). These results indicated that the exchangeable and strongly bonded fractions of arsenic in non-mined soil, capped and uncapped tailings that were extracted with $0.05 \mathrm{M}$ EDTA buffered at $\mathrm{pH} 7$ decreased with the application of beringite at 4, 8 and 12 WAI (Sabiene, Brazuaskiene \& Rimmer, 2004; Xu, Xie \& Xue, 2011; Garau,Castaldi, Santona, Deiana, \& Melis, 2007). The extracting solution, Ammonium-EDTA (0.05 M, pH 7) extracted significantly lower concentrations of As compared to un-amended non-mined soil capped and uncapped tailings due to the formation of As complexes that are strongly bonded in the inner sphere of beringite (Pacwa-Plocini, Plaza, Piotrowska-Seget \& Cameotra, 2011; Rascio \& Navari-Izzo, 2011). The complexation of As to form calcium arsenate occurs in the inner sphere of berringite that is a constituent of beringite. Furthermore, the adsorption of As due to the presence of $\mathrm{Ca}^{2+}$ and $\mathrm{Mg}^{2+}$ ions in beringite contributes to a decrease in extractable As in contaminated soil (Bhargava, Carmona, Bhargava \& Srivastava., 2012; Trgo, Peric \& Vukojevic-Medvdovic, 2006; Shazia, Alia, Iftikhar, \& Muhammad, 2015). The presence of bivalent cations, in berringite that is a constituent of beringite, aids in the adsorption of As which is not easily desorbed (Pubmed, Elena, Elizabeth, \& Rosanna, 2011; Valeska, Elena, Luz, Michel, Alexander, \& Rosanna., 


\section{Al Macrothink}

Journal of Agricultural Studies

ISSN 2166-0379

2018, Vol. 6, No. 1

2012; Rajindiran, Dotaniya, Vassanda Coumar, Panwar, \& Saha, 2015). The adsorption and complexation of As through the application of beringite could therefore be the major factors contributing to the concentration of As-EDTA compared to the control. A decrease of $34 \%$ in extractable arsenic in contaminated soil has similarly been obtained and attributed to the presence of bivalent cations $\left(\mathrm{Ca}^{2+}\right.$ and $\left.\mathrm{Mg}^{2+}\right)$ in beringite that aid in the adsorption of arsenic (Ruttens \& Boulet, 2011; Saha, 2014).

The rate of application of zeolite resulted in an insignificant $(\mathrm{P}=0.05)$ concentration of EDTA-extractable arsenic compared to un-amended non-mined soil when applied at 4 WAI (Table 5). Also, at 8 and 12 WAI, the concentrations of EDTA-As were similar $(\mathrm{P}=0.05)$ in zeolite-amended non-mined soil at rates 30 and $60 \mathrm{~kg} \mathrm{ha}^{-1}$ with values in the ranges of 19.55 $\mathrm{mg} \mathrm{kg}^{-1}$ to $19.62 \mathrm{mg} \mathrm{kg}^{-1}$ and $19.41 \mathrm{mg} \mathrm{kg}^{-1}$ to $19.48 \mathrm{mg} \mathrm{kg}^{-1}$, respectively but significantly lower $(\mathrm{P}=0.05)$ than non-amended soil (Table 3$)$.

Table 2. Effects of rate of application and type of amendment on EDTA- extractable arsenic of non-mined soil as affected by incubation period

\begin{tabular}{|c|c|c|c|c|}
\hline \multirow[t]{3}{*}{ Amendments } & \multirow{3}{*}{$\begin{array}{l}\text { Rate of } \\
\text { application } \\
\text { (kg ha ) }\end{array}$} & & Weeks after & incubation \\
\hline & & & 4 & 12 \\
\hline & & & \multicolumn{2}{|c|}{ EDTA - extractable As $\left(\mathrm{mg} \mathrm{kg}^{-}\right)$} \\
\hline \multirow[t]{3}{*}{ Zeolite } & 0 & 20.01 & 19.95 & 20.04 \\
\hline & 30 & 19.73 & 19.62 & 19.55 \\
\hline & 60 & 19.65 & 19.48 & 19.41 \\
\hline \multirow[t]{3}{*}{ Beringite } & 0 & 19.76 & 19.79 & 20.20 \\
\hline & 30 & 17.02 & 16.35 & 16.18 \\
\hline & 60 & 15.46 & 14.72 & 14.34 \\
\hline
\end{tabular}

$\operatorname{LSD}(0.05): .2 .63$

Table 3. Effects of rate of application and type of amendment on EDTAextractable arsenic of capped tailings as affected by incubation period

Amendments $\begin{gathered}\text { Rate of application } \\ \left(\mathrm{kg} \mathrm{ha}^{-}\right)\end{gathered}$
$\begin{gathered}4 \\ \text { EDTA - }- \text { Wextractable As }\left(\mathrm{mg} \mathrm{kg}^{-}\right)\end{gathered}$




\begin{tabular}{|c|c|c|c|c|}
\hline \multirow[t]{3}{*}{ Zeolite } & & 178.6 & 177.9 & 177.5 \\
\hline & 30 & 178.0 & 176.9 & 176.4 \\
\hline & 60 & 177.1 & 175.1 & 174.6 \\
\hline \multirow[t]{3}{*}{ Beringite } & 0 & 179.2 & 178.8 & 179. \\
\hline & 30 & 160.7 & 156.6 & 153 \\
\hline & 60 & 135.3 & 129.8 & 123 \\
\hline
\end{tabular}

$\operatorname{LSD}(0.05): .18 .6$

Table 4. Effects of rate of application and type of amendment on EDTAextractable arsenic of uncapped tailings as affected by incubation period

\begin{tabular}{lllc}
\hline Amendments & $\begin{array}{l}\text { Rate of application } \\
(\mathrm{kg} \mathrm{ha})\end{array}$ & \multicolumn{2}{c}{ Weeks after incubation } \\
\cline { 3 - 3 } & 4 & 8 & 12 \\
\cline { 3 - 3 } & & EDTA-extractable As $\left(\mathrm{mg} \mathrm{kg}^{-}\right)$
\end{tabular}

\begin{tabular}{lllll}
\hline Zeolite & 0 & 789.0 & 789.7 & 790.3 \\
& 30 & 787.4 & 785.8 & 784.7 \\
& 60 & 786.1 & 784.5 & 783.5 \\
Beringite & 0 & 789.8 & 789.3 & 790.4 \\
& 30 & 744.8 & 743.1 & 738.7 \\
& 60 & 725.9 & 722.5 & 716.2
\end{tabular}

$\operatorname{LSD}(0.05): 2.90$

\subsection{Effects of Amendments on Water-soluble Arsenic in Non-mined Soil, Capped and Uncapped Tailings}

Tables 5, 6 and 7 show the results of the effects of the application zeolite and beringite on water soluble arsenic in non-mined soil, capped and uncapped tailings. The levels of water soluble arsenic (As-water) after the application of either $30 \mathrm{~kg} \mathrm{ha}^{-1}$ or $60 \mathrm{~kg} \mathrm{ha}^{-1}$ beringite to non-mined soil, capped and uncapped tailings resulted in significant $(P=0.05)$ successive decreases in As-water at 4, 8 and 12 WAI compared to un-amended soil (Tables 5, 6 and 7). The decrease in extractable arsenic in contaminated soil/tailings occurred possibly due to the presence of bivalent cations $\left(\mathrm{Ca}^{2+}\right.$ and $\left.\mathrm{Mg}^{2+}\right)$ in beringite that aid in the adsorption of arsenic (Shazia, Alia, Iftikhar, \& Muhammad, 2015). This could have resulted in the significantly lower concentration of As-water of beringite-amended soil/tailings compared to un-amended samples. The reduction in extractable As-EDTA (Tables 2, 3 and 4) as a result of the complexation of arsenic to form calcium arsenate in the inner sphere of ettringite that is a constituent of the beringite structure and the sorption of As in beringite (Rascio \& 


\section{NI Macrothink}

Journal of Agricultural Studies

ISSN 2166-0379

2018, Vol. 6, No. 1

Navari-Izzo, 2011) could also be assigned to the significantly lower $(\mathrm{P}=0.05)$ concentration of water soluble As in beringite-amended samples compared to un-amended samples in non-mined, capped and uncapped tailings (Tables 5, 6 and 7). There was no significant difference in the level of As-water between zeolite applied at either $30 \mathrm{~kg} \mathrm{ha}^{-1}$ or $60 \mathrm{~kg} \mathrm{ha}^{-1}$ and un-amended uncapped tailings at $4 \mathrm{WAI}(\mathrm{P}=0.05)$. At 8 and $12 \mathrm{WAI}$, the application of $60 \mathrm{~kg} \mathrm{ha}^{-1}$ zeolite gave the same effects as un-amended uncapped tailings $(\mathrm{P}=0.05)$ (Table 7). The insignificantly different concentrations of water soluble As compared to un-amended samples at the $60 \mathrm{~kg} \mathrm{ha}^{-1}$ rate of application (Table 7) indicates that zeolite is not effective in remediating/immobilizing arsenic in uncapped tailings.

The high $\mathrm{pH}$ of zeolite $(7.0-9.2)$ and the resultant neutral to slightly alkaline $\mathrm{pH}$ of zeolite-amended uncapped tailings $(7.3-7.5)$ could lead to a decrease in the sorption of As. The concentration of water soluble As was not significantly different between un-amended samples and non-mined soil/capped tailings amended with either $30 \mathrm{~kg} \mathrm{ha}^{-1}$ or $60 \mathrm{~kg} \mathrm{ha}{ }^{-1}$ zeolite throughout the incubation periods at 4, 8 and $12 \mathrm{WAI}(\mathrm{P}=0.05)$ (Tables 5 and 6$)$. The concentration of As-EDTA adsorbed onto the soil/tailings was not significantly different with the application of either $30 \mathrm{~kg} \mathrm{ha}^{-1}$ or $60 \mathrm{~kg} \mathrm{ha}^{-1}$ zeolite compared to un-amended capped tailings at the end of the incubation experiment (Table 4). This implies that there were slight and insignificant $(\mathrm{P}=0.05)$ changes in the adsorption of extractable and available arsenic within the soil matrix. Hence the insignificantly $(\mathrm{P}=0.05)$ different levels of water soluble arsenic extracted from zeolite and un-amended capped tailings.

Table 5.Effects of rate of application and type of amendment on water

soluble arsenic of non-mined soil as affected by incubation period

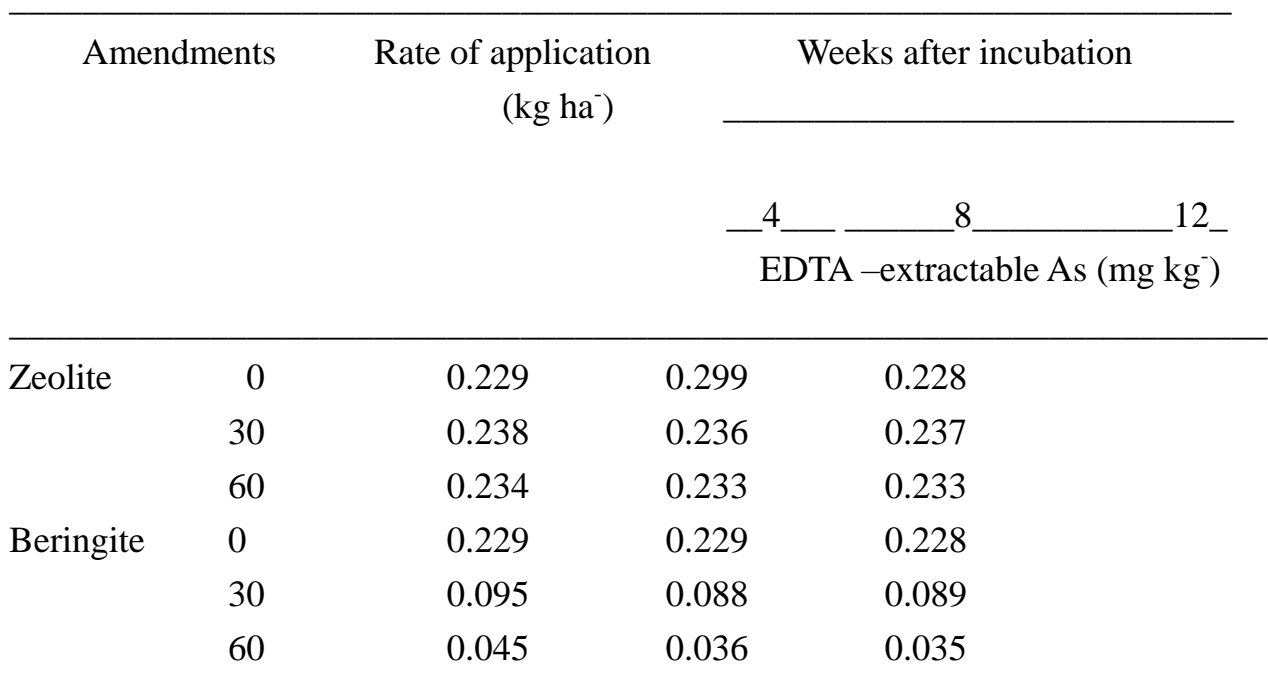

$\operatorname{LSD}(0.05): 0.134$ 
Table 6. Effects of rate of application and type of amendment on water soluble arsenic of capped tailings as affected by incubation period

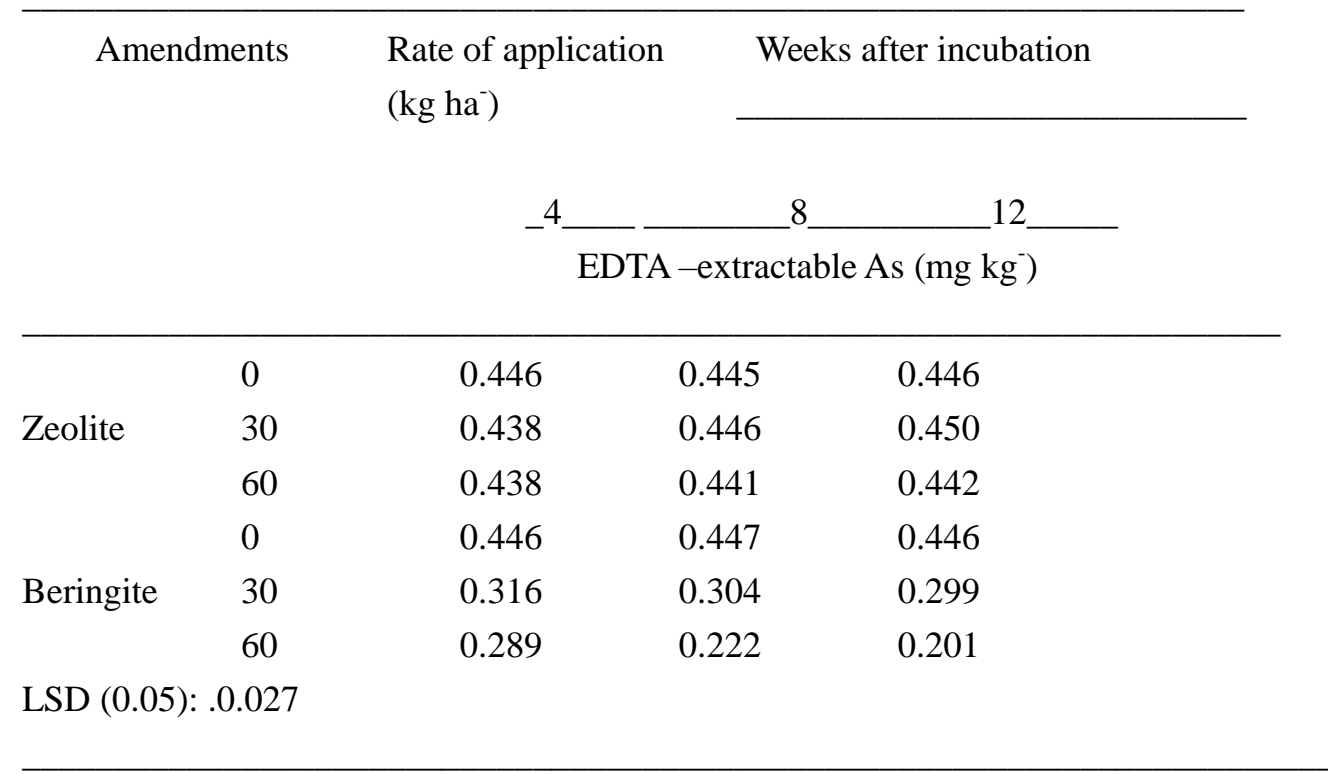

Table 7. Effects of rate of application and type of amendment on water soluble arsenic of uncapped tailings as affected by incubation period

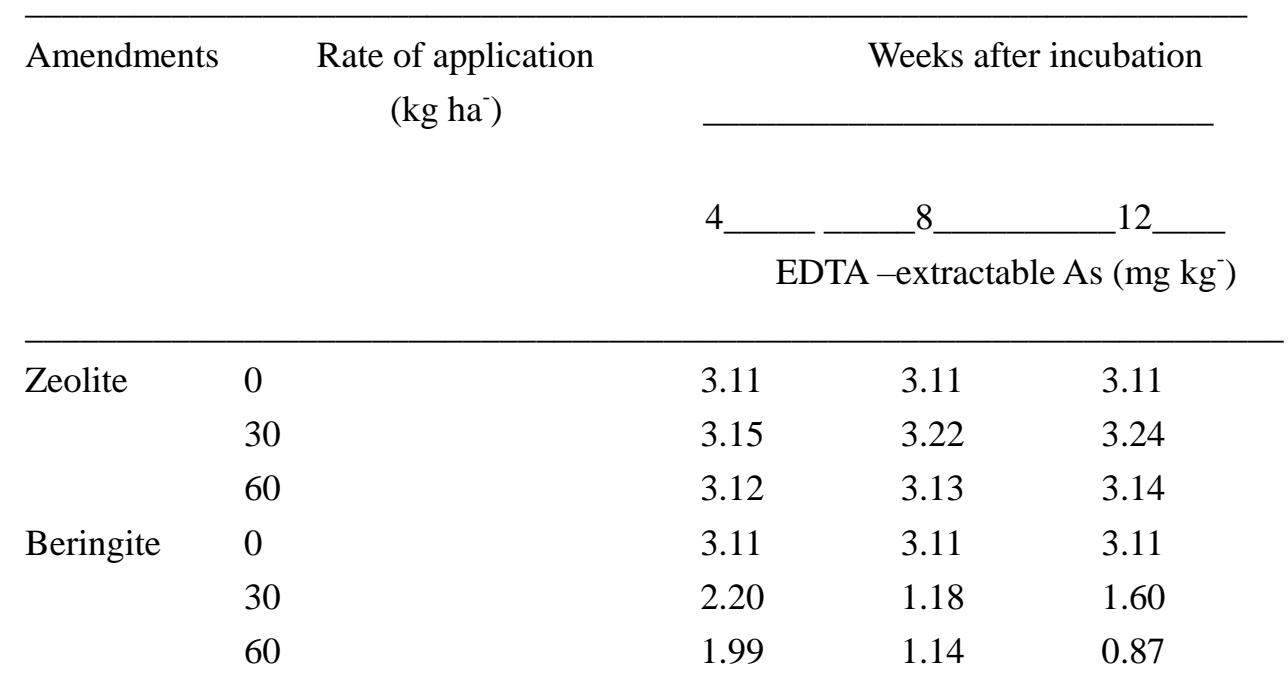

$\operatorname{LSD}(0.05): .0 .11$ 


\section{Macrothink}

\subsection{Concentration of Arsenic in Lactuca sativa grown on Mediated Soil/Tailings}

Edible plants grown on polluted soil can accumulate potentially toxic elements at high concentrations that pose a threat to human health (Vosta, Graminas \&Samara, 1996; Sharma, Bangar, Rajesh Jain. \& Sharma., 2004; Wauchope, 1983). Ultimately, lettuce was cropped on mediated soil/tailings so as to assess the uptake and toxicity levels of As. Figures 1, 2 and 3 show the results of the concentration of Arsenic in lettuce (Lactuca sativa) harvested from non-mined soil, capped and uncapped tailings after mediation with beringite and zeolite. Arsenic (As) accumulated in the aerial part of the lettuce plant has been used as an index of bioavailability for the purpose of this study. Generally, the concentration of As in zeolite and beringite-amended soil/tailings were significantly lower than that of un-amended samples ( $\mathrm{P}$ $=0.05)$ (Figures 1, 2 and 3).

3.4 Bioavailability of Arsenic in Lettuce Grown on Soil/Tailings Amended with Zeolite and Beringite

The concentration of arsenic accumulated in lettuce ranged from $0.27-4.13 \mathrm{mg} \mathrm{kg}^{-1}$. This concentration of arsenic is within the limits given by (FSA, 2007). Plants that are not hyper-accumulating species accumulate arsenic in a normal range of $0.1-5 \mathrm{mg} \mathrm{As} \mathrm{kg} \mathrm{dry}^{-1}$ weight in their leaves (FSA, 2007).

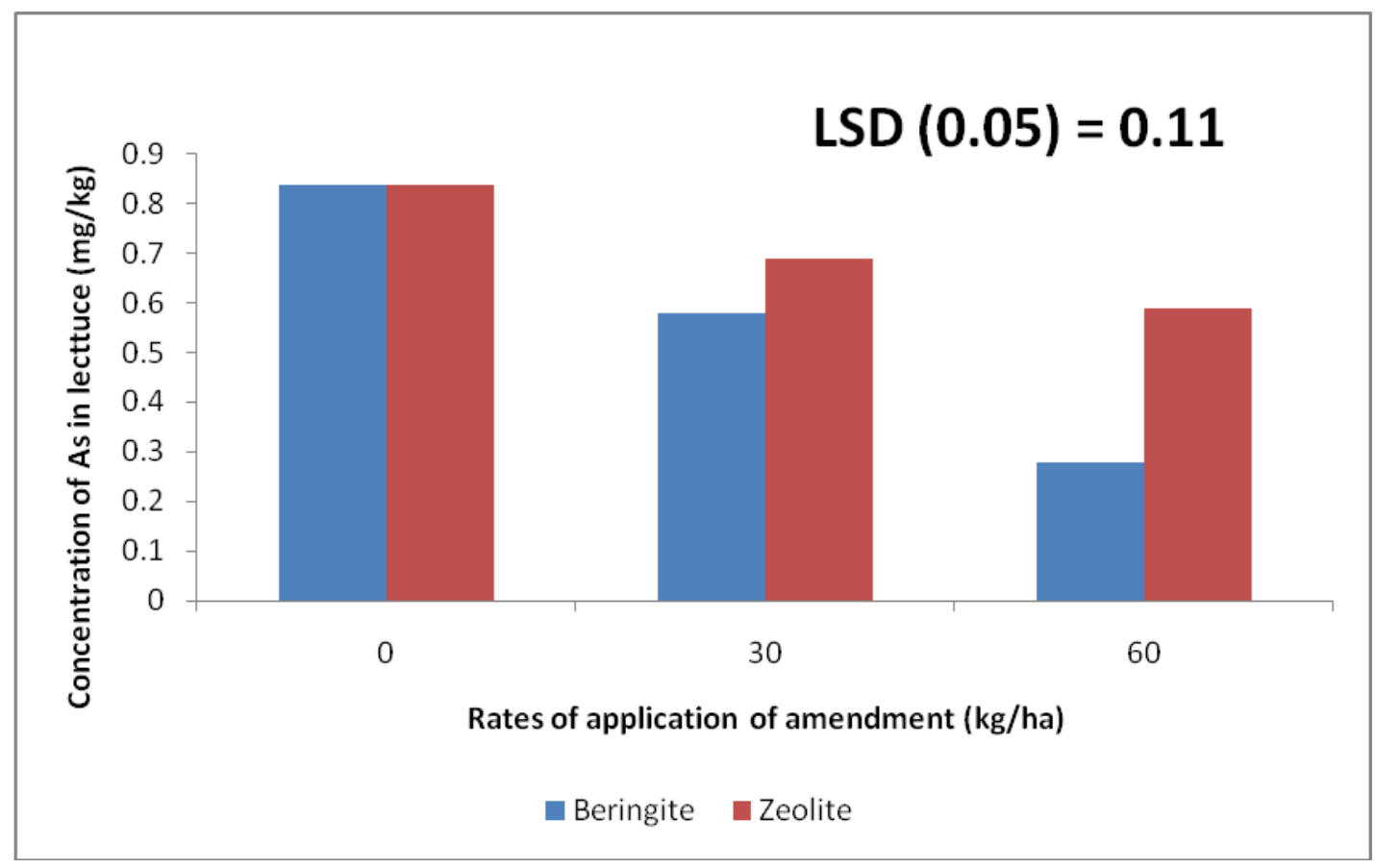

Figure 1. Bioavailability of As in Lactuca sativa L. grown on amended non-mined soil 


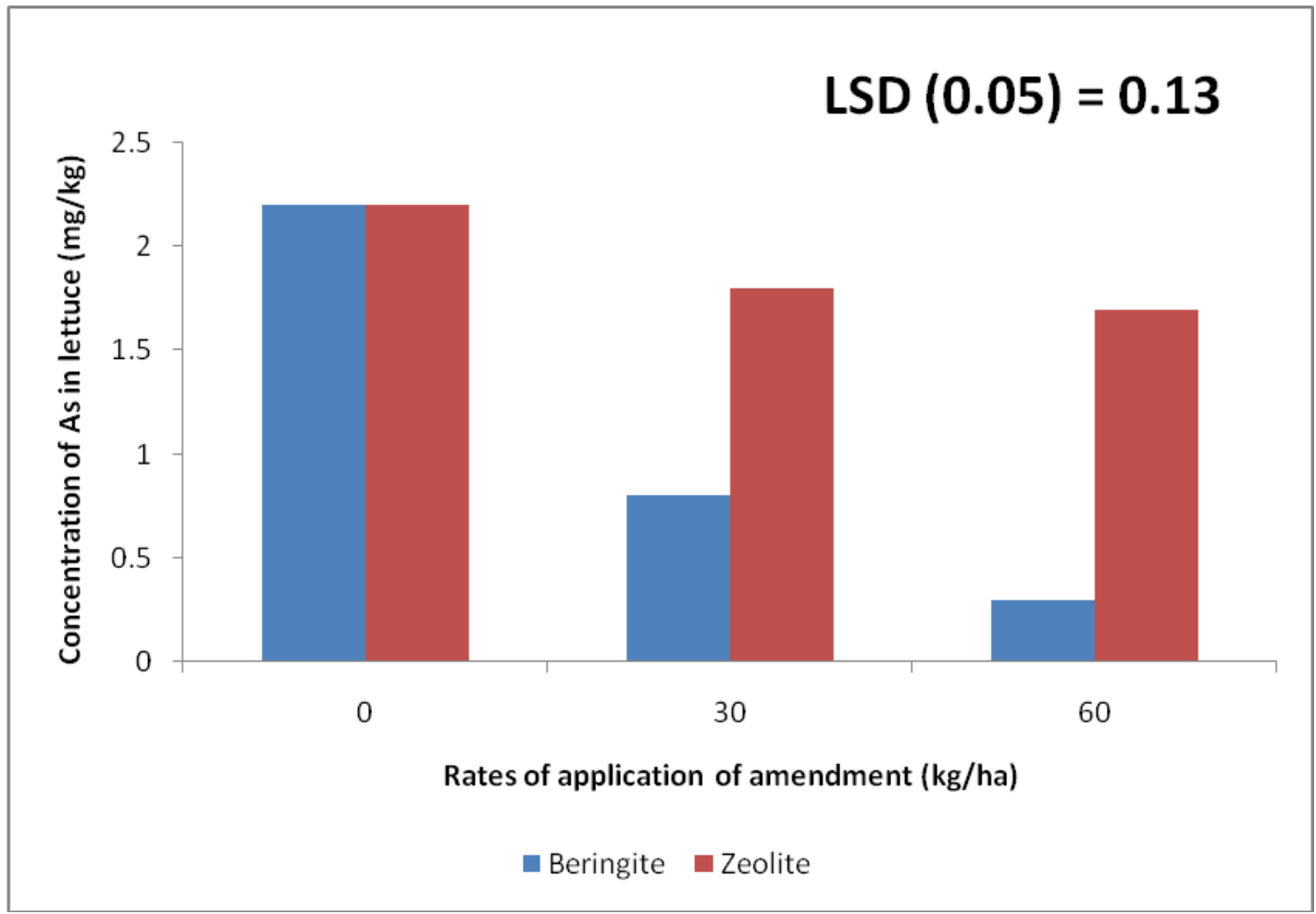

Figure 2. Bioavailability of As in Lactuca sativa L. grown on amended capped tailings

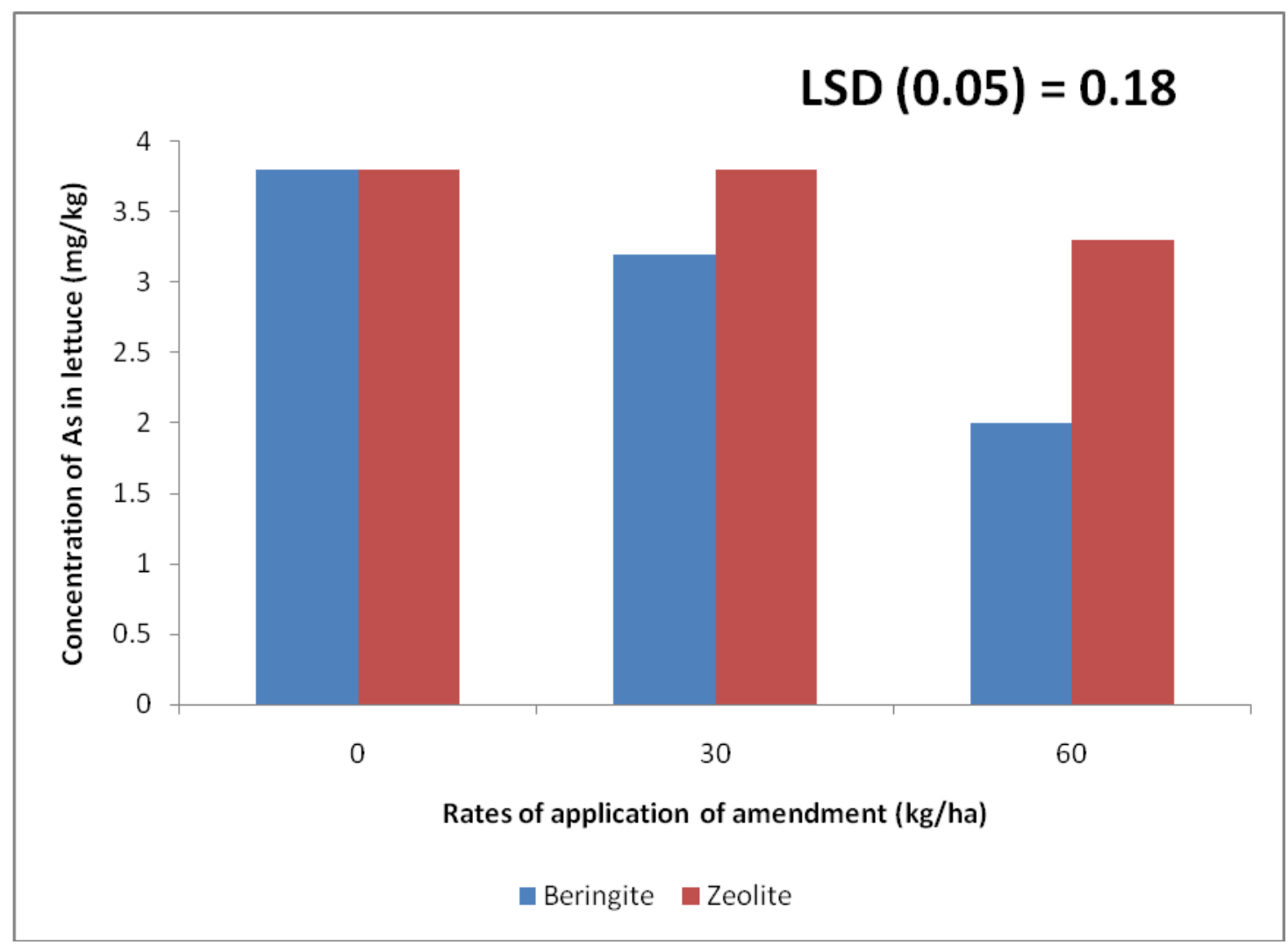

Figure 3. Bioavailability of As in Lactuca sativa L. grown on amended uncapped tailings 
Except for the non-mined soil, there were no significant $(\mathrm{P}=0.05)$ differences in the concentration of arsenic in lettuce grown in either $30 \mathrm{~kg} \mathrm{ha}^{-1}$ or $60 \mathrm{~kg}^{-1} \mathrm{ha}^{-1}$ zeolite amended soil/tailings (Figures 1, 2 and 3). However, the application of zeolite at $60 \mathrm{~kg} \mathrm{ha}^{-1}$ resulted in a significantly $(\mathrm{P}=0.05)$ lower concentration of arsenic in lettuce compared to un-amended soil/tailings. This trend was observed due to minimal effects of zeolite on As-EDTA and water soluble Arsenic (Tables 5-7) in non-mined soil, capped and uncapped tailings. Non-mined soil mediated with zeolite resulted in a lower content of As in lettuce aerial biomass. The concentration of arsenic in un-amended non-mined soil (Figure 1) was lower than the UK standard of $1.0 \mathrm{mg} \mathrm{As} \mathrm{kg}^{-1}$ dry mass (FAO \& WHO, 2001). On the other hand, capped and uncapped tailings amended with zeolite resulted in the concentrations of arsenic in lettuce plants (Figures 2 and 3 ) that were above the UK acceptable limits for food (FAO \& WHO, 2001) The cause of arsenic contamination may not necessarily be geologic in origin but anthropogenic. This is because the concentration of arsenic in lettuce grown on non-mined soil was within acceptable limits despite the underlying arseno-pyritic rocks. The beneficiation of gold in the study area is from arseno-pyrite rock ores which result in the release of high amounts of As during gold ore processing into the feed of tailings effluent, capped and uncapped tailings. The effects of mining activities in arsenic contamination were manifested through the concentrations of arsenic in lettuce that were above the UK acceptable limits for food. The application of beringite to soil/tailings resulted in the least content of arsenic in lettuce plants. The concentrations of arsenic in lettuce plants grown in un-amended non-mined soil, capped and uncapped tailings were $0.83,2.13$ and $3.87 \mathrm{mg} \mathrm{kg}^{-1}$, respectively (Figures 1, 2 and 3). These were in contrast to the lower arsenic values of $0.27-$ $0.47 \mathrm{mg} \mathrm{kg}^{-1}, 0.37-0.83 \mathrm{mg} \mathrm{kg}^{-1}$ and $2.1-3.23 \mathrm{mg} \mathrm{kg}^{-1}$ in lettuce cultivated on beringite-mediated non-mined soil, capped and uncapped tailings respectively. The significantly lower concentration of arsenic in lettuce could be attributed to the significantly immobilized arsenic by beringite and lower concentrations of EDTA-extractable (Tables $2-4$ ) and water soluble arsenic (Tables $5-7$ ) in beringite-amended soil/tailings. The concentration of arsenic in lettuce grown in beringite-mediated capped tailings was therefore lower than the

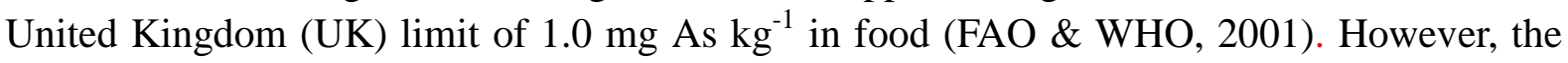
concentrations of arsenic in lettuce cultivated on un-amended capped tailings $\left(2.13 \mathrm{mg} \mathrm{kg}^{-1}\right)$ (Figure 2) and amended uncapped tailings (2.1 - $3.23 \mathrm{mg} \mathrm{kg}^{-1}$ (Figure 3) was higher than the UK acceptable limit of $1.0 \mathrm{mg} \mathrm{As} \mathrm{kg}^{-1}$. Heavy metals in the soil can be absorbed by plants. The health of humans and other organisms can be adversely affected through the ingestion of both water and food that have been contaminated by the soil According to FAO \& WHO (2001), arsenic toxicity usually occurs through contaminated food and drinking water. This implies that it would be safe to crop only on beringite-mediated capped tailings but not on either un-amended capped tailings or beringite-amended uncapped tailings.

\section{Conclusion}

Beringite was more effective in adsorbing and immobilizing arsenic experimental soil/tailings as compared to zeolite. The bioavailability test using lettuce, a leafy vegetable indicated that beringite applied at $60 \mathrm{~kg} \mathrm{ha}^{-1}$ reduced As below the recommended maximum limit of Food and Agriculture Organization $\left(1.0 \mathrm{mg} \mathrm{kg}^{-1}\right)$. Although the study was done in a pot/laboratory, 
field trials would be necessary to consolidate the potential of beringite in remediating arsenic contaminated soils, most especially at mine-contaminated sites.

\section{References}

ADAS. The Analysis of Agricultural Materials. (1986). Manual of Methods. London: Agricultural Development and Advisory Services, No 427 Ed.3 pp. 248. HMSO Publication, London

Bhargava, A., Carmona, F.F., Bhargava, M. \&Srivastava, S. (2012). Approaches for enhanced phytoextraction of heavy metals. Journal of Environmental Management, 105, 103-120. https://doi.org/10.1016/j.jenvman.2012.04.002

Date, Y., Terakado, S., Sasaki, K., Aota, A., Matsumoto, N., Shiku, H., Inoa, K., Watanabe, Y., Matsue, T., \& Ohmura, N. (2012). Microfluidic heavy metal immunoassay based on absorbance measurement. Biosens. Bioelectron, 33, 106-112.

https://doi.org/10.1016/j.bios.2011.12.030

Edwards, R., Rebedea, I., Lepp, N. W., \& Lovell, A. J. (1999). An investigation into the mechanisms by which synthetic zeolites reduce labile metal concentrations in soils. Environmental Geochemistry and Health, 21, 157-173.

https://doi.org/10.1023/A:1006677115486

Food and Agricultural Organization \& World Heaith Organization (FAO \& WHO). (2001). Food additives and contaminants, Joint FAO/WHO foo standards proram 2001.

ALINORMN01/12A:1 - 289, Rome: FAO/WHO.. .

FSA. (2007). The Food Standards Agency. Retrieved from The Food Standards Agency http://www.food.gov.uk/multimedia/pdf/fsismetals.

Garau, G., Castaldi, P., Santona, L., Deiana, P., \& Melis, P. (2007). Influence of red mud, zeolite and lime on heavy metal immobilization, culturablh Heterotr populations and enzyme activities in contaminated soil. Geoderma, 142, 47-57.

https://doi.org/10.1016/j.geoderma.2007.07.011

GenStat discovery $3^{\text {rd }}$ edition, (2016). GenStat procedure library release PL 15.2. London VSN International Limited.

Grubben, G. J. H. (2004). ' Lactuca Sativa L'. Record from Protobase, G. .J. H. \& Denton, O. A. Editors, PROTA (Plant Resources of Tropical Africa / Resources vegetables de l'Afrique tropicale), Waginingen, Netherlands. Retrieved from http://www.prota4u.org.

Jiang, W., Tao, T. \& Liao, Z (2011). Removal of heavy metal from contaminated soil with chelating agents. Open Journal of Soil Science, 1 70-76.

https://doi.org/10.4236/ojss.2011.12010

Mench, M., Vangronsveld, J., Beckx, C., \& Ruttens, A. (2006). Progressi in assisted natural remediation of an arsenic contaminated agricultural soil. Environmental Pollution, 144, 51-56. https://doi.org/10.1016/j.envpol.2006.01.011 
Nadia, G., \& Zaghloul, A. M.(2007). Minimizing the human health hazard of lettuce cultivated in some heavy metals affected soils. Australian Journal of Basic and Applied Sciences, 1(2), 79-86.

Oste, L. A., Lexmond, T. M., \& Van Riemsdijk, W. H. (2002). Metal immobilization in soils using synthetic zeolites. Journal of Environmental Quality, 31, 813-821.

https://doi.org/10.2134/jeq2002.8130

Pacwa-Płociniczak, M., Płaza, G.A., Piotrowska-Seget, Z. \& Cameotra, S.S. (2011). Environmental applications of biosurfactants. Recent Advances in International Journal of Molecular Science, 12, 633-654. https://doi.org/10.3390/ijms12010633

PubMed, V. C., Elena B., Elizabeth T, \& Rosanna G. (2011). Simultaneous immobilization of metals and arsenic in acidic polluted soils near a copper smelter in central Chile. Environmental Science and Pollution Research, 19(4), 1131-43.

Rajindiran, S., Dotaniya, M.L., VassandaCoumar, M., Panwar, N.R. \& Saha, J.K. (2015). Heavy metal polluted soils in India: status and counter measures. Research Journal, 49(3), 320-337.

Rascio, N. \&Navari-Izzo, F. (2011). Heavy metal hyper accumulating plants: How and what do they do it? and what makes them so interesting? Plant Science, 180, 169-181. https://doi.org/10.1016/j.plantsci.2010.08.016

Ruttens, A. \&Boulet, J. (2011 ). Short rotation coppice culture of willows and poplars as energy crops on metal contaminated agricultural soils. International Journal of Phytoremediation, 13,194-207. https://doi.org/10.1080/15226514.2011.568543

Sabiene, N., Brazuaskiene, D. M., \& Rimmer, D. (2004). Determination of heavy metal mobile forms by different extraction methods. Ekologija, 1, 36-41.

Saha, J. K. (2014). Integrated management of polluted soils for enhancing productivity and quality of crops. In . Gaur, R.K. \& Sharma P. (Eds). Approaches to plant stress and their management (pp. 1-21), Shaha, India, Springer. https://doi.org/10.1007/978-81-322-1620-9_1

Sharma, O. P., Bangar, K. S., Rajesh Jain, K. S., \& Sharma, P. K..(2004). Heavy metals accumulation in soils irrigated by municipal and industrial effluent. Journal of Environmental Science Engineering, 46, 65-73.

Shazia, G, Alia N., Iftikhar F. \& Muhammad, I. (2015). Reducing heavy metals extraction from contaminated soils using organic and inorganic amendments - a review. Pollution Journal of Environmental Studies, 24 (3),1423-1426.

Trgo, M., Peric, J., \& Vukojevic-Medvdovic, N. (2006). Investigations of different kinetic models for zinc ions uptake by natural zeolite tuff. Journal of Environmental Management, 79, 298-304. https://doi.org/10.1016/j.jenvman.2005.07.009

U.S. Environmental Protection Agency (US EPA). (2003). United States Environmental Protection Agency's Web site. Retrieved from http://www.epa.gov/. 


\section{Macrothink}

Journal of Agricultural Studies

ISSN 2166-0379

2018, Vol. 6, No. 1

Valeska, C., Elena, B., E. T., Luz, M. F., Michel M., Alexander, N. \& Rosanna G. (2012). Simultaneous immobilization of metals and arsenic in acidic polluted soils near a copper smelter in central Chile. Environmental Science and Pollution Research, 19 (4):1131-1143. https://doi.org/10.1007/s11356-011-0673-3

Vousta, D. A., Graminas, A., \& Samara, C .(1996). Trace elements in vegetables grown in an industrial area in relation to soil and air particulate matter. Environmental Pollution,94, 325-335. https://doi.org/10.1016/S0269-7491(96)00088-7

Wauchope, R. D.(1983). Uptake, translocation and phytotoxicity of arsenic in plants. In W. H. Lederer, \& R. J. Fensterheim (Eds.), Arsenic: Industrial, Biomedical, Environment Perspectives. (pp. 1-12). New York: Van Nostrand Reinhole.

Xu, Y., Xie, Z. \& Xue, L. (2011). Chelation of heavy metals by potassium butyl di thio phosphate. Journal of Environmental Science, 23: 778-783.

https://doi.org/10.1016/S1001-0742(10)60477-9

\section{Copyright Disclaimer}

Copyright for this article is retained by the author(s), with first publication rights granted to the journal.

This is an open-access article distributed under the terms and conditions of the Creative Commons Attribution license (http://creativecommons.org/licenses/by/4.0/). 